\title{
Sexuality in Medieval and Early Modern Art: From the Corbels and Misericords to Late Medieval Manuscript Illustrations ${ }^{1}$
}

\author{
Albrecht Classen* \\ University of Arizona
}

*Corresponding Author: Albrecht Classen, University of Arizona

\begin{abstract}
The history of sexuality concerns many aspects, including private life, the Church, literature, the laws, and also the arts. While we have previously mostly assumed that sexuality was a taboo for the Christian world, a closer analysis demonstrates that there were many examples of medieval art in churches all over Europe that critically engage with human sexuality, either as a sin or as an ordinary necessity, as a danger or as an important vehicle to reach out to people and probe basic moral and ethical issues. But this article also illustrates that medieval artists were keenly interested in the topic of sex, as countless examples in manuscript illustrations demonstrate. Sex means procreation, but it also met fundamental human needs, which explains why there is much sexual humor in medieval art.
\end{abstract}

Keywords: Sexuality in Medieval Art; Misericords; Pilgrim Badges; Corbels; Manuscript Illuminations; Meister E.S.; Hortus Conclusus; Benedict of Nursia; Taddeo Di Bartolo; Fountain of Youth; Anthony of Burgundy; Hausbuch Wolfegg; Hans Memling;

This paper endeavors to explore what we could learn about human sexuality in medieval and early modern art. Although scholarship has begun to explore such features as grotesque misericords and corbels, many questions regarding the appropriate interpretation of such images remain unanswered. The first task will be to identify and circumscribe the corpus of relevant documents in medieval art, and then we can try to discuss them more in depth than has been done so far. In order to achieve this goal, we must first establish the larger context, take into consideration biblical, theological, legal, and literary statements, and then embed the medieval images in that context. The history of sexuality has long been recognized as fundamental for the history of mentality, but we have not yet integrated relevant wood or stone carvings, oil paintings, metal objects (pilgrimage badges) or frescoes sufficiently enough to compensate for the seemingly overarching and repressive influence which the Catholic Church exerted on medieval and early modern society and which the discussion of sex in medieval art will qualify to some extent. ${ }^{2}$

The oldest text relevant for all Jews, Christians, and also Muslims, the Book of Genesis in the Old Testament, does not hold back in its explicit discussion of sexuality, nakedness, shame, genitals, and the human body. After Adam and Eve have eaten from the forbidden fruit, "the eyes of them both were opened, and when they perceived themselves to be naked, they seek together fig leaves and made themselves aprons." ${ }^{3}$ Once God has called upon Adam, asking him why he is hiding in the bushes, the culprit responds, speaking for all subsequent mankind: "and I was afraid because I was naked, and I hid myself" (3:15). Once God has learned the truth, which he knew anyway, and has condemned both the two sinners and the snake, "God made for Adam and his wife garments of skins

1. It is my pleasure to express my gratitude to Prof. Assaf Pinkus and the Tel Aviv University, Israel, for the invitation to present a short version of this study as the Keynote Lecture at the conference "Sexuality and Intimacy in Medieval and Early Modern Art," March 8, 2017. I would like to thank the audience for the rich discussion and very positive response to my arguments.

2. Peter Dinzelbacher, "Sexualität/Liebe: Mittelalter," Europäische Mentalitätsgeschichte: Hauptthemen in Einzeldarstellungen, ed. id. Crooners Taschenausgabe, 469. 2nd rev. and expanded ed. (1993; Stuttgart: Alfred Kröner Verlag, 2008), 80-101, with an extensive bibliography.

3. Genesis, Chapter 3, p. 15. Quoted from The Vulgate Bible. Vol. 1: The Pentateuch. Douay-Rheims Translation, ed. Swift Edgar. Dumbarton Oaks Medieval Library (Cambridge, MA, and London: Harvard University Press, 2010). 
and clothed them" 17). Ever since, human nakedness has been associated with shamefulness, as even God did not want the two creatures to walk around naked outside of Paradise. However, this development, that is, the growth of sexuality, made it possible for the two to procreate and thus to become the founding parents of all mankind, at least according to the biblical story.

Human life has continued ever since because of sexuality, but this basic drive in virtually all people has also been a source of major contention, conflict, violence, and then also love, friendship, companionship, and peace. This physical attraction makes it possible for members of the opposite sex to bond and to sleep with each other, thus creating progeny, here not discounting or disregarding homosexuality as an alternative form of sexual relationship. Nevertheless, as we all know only too well, sexuality has thereby also become one of the greatest sources of harassment, molestation, and rape, both in secular society and within the world of clerics. We are facing two sides of the same coin, which explains why people throughout time have struggled so hard with this phenomenon, to accept it as something very beautiful and exciting, or to condemn it as something morally debasing human beings, not to talk about all the violence associated with it.

The entire world of the medieval and early modern Church, along with the respective lawyers and judges, has dealt with sexual violations, and this issue in its myriad manifestations has continued to be most difficult also in modern society, both in East and West. Not surprisingly, virtually all medieval secular law books, penitentiaries, and canon law books, for instance, are filled with countless specific rulings regarding the punishment of sexual transgressions, both outside and also within marriage, as James A. Brundage has already taught us in his magisterial book on this topic, ${ }^{4}$ and yet, the more the Church has tried to suppress sexuality as a spiritual danger for the human soul, the more it seems to have resurfaced, also in many different art forms and literature, so when we consider, for instance, an illustration in a tenth-century manuscript containing Prudentius's Psychomachia where libido is killed by pudicitia. ${ }^{5}$ Most theological literature or religious narratives confirmed this pervasive abhorrence of the physical side of human life, but we cannot simply take such negative arguments and images as all-decisive throughout the Middle Ages. The south portal of the Cluniac abbey church of Saint-Pierre in Moissac in Southern France, for instance, is decorated with a moving, if not terrifying pair, one showing death, the other the rotting corpse of a nude female, which obviously served to alert the parishioners to be forewarned against enjoying the sexual pleasures and always to keep the end of life in mind.

Nevertheless, sexuality has always been a fact of life, both in its constructive and deconstructive manifestation, including both love and violence, pleasure and crime (rape). ${ }^{6}$ As Garthine Walker now correctly confirms, "Sexuality is integral to a host of categories of (gender, race, class, status, and age, for example), topics such as religion, kinship and family formation, courtship and marriage, the household, social relations, demography, life cycle, the body, childhood, the rise of the state, crime in general and certain crimes in particular ...." Little wonder that such great scholars such as Michel Foucault, Lucien Febvre, Bronislaw Malinowski, Emile Durkheim, and Max Weber have paid plenty of attention to this topic as well. ${ }^{8}$ Much of medieval literature is deeply determined by the themes of the eros, that is, love and sexuality, as we have recognized already for a long time, ${ }^{9}$ and we find

4. James A. Brundage, Law, Sex, and Christian Society in Medieval Europe (Chicago and London: The University of Chicago Press, 1987).

5. Bern, Burgerbibliothek, Cod. 264, p. 72; here quoted from Gabriele Bartz, Alfred Karnein, and Claudio Lange, Liebesfreuden im Mittelalter: Kulturgeschichte der Erotik und Sexualität in Bildern und Dokumenten (Stuttgart and Zürich: Belser Verlag, 1994), 10.

6. Violence Against Women in Medieval Texts, ed. Anna Roberts (Gainesville, Tallahassee, et al., Fl: University Press of Florida, 1998); Albrecht Classen, Sexual Violence and Rape in the Middle Ages: A Critical Discourse in Premodern German and European Literature. Fundamentals of Medieval and Early Modern Culture, 7 (Berlin and Boston: Walter de Gruyter, 2011).

7. Garthine Walker, "Framing Premodern Desires Between Sexuality, Sin, and Crime: An Introduction," Framing Premodern Desires: Sexual Ideas, Attitudes, and Practices in Europe, ed. Satu Lidman, Meri Heinonen, Tom Linkinen, and Marjo Kaartinen. Crossing Boundaries (Amsterdam: Amsterdam University Press, 2017), 9-26; here 11-12.

8. See Walker's bibliography for a good selection of relevant studies (see note 7).

9. See, for instance, John W. Baldwin, The Language of Sex: Five Voices from Northern France Around 1200. The Chicago Series on Sexuality, History, and Society (Chicago and London: The University of Chicago Press, 
numerous theological discussions about both aspects as well, ${ }^{10}$ but to what extent can we find their expression in the visual arts as well? To what extent would medieval artists have even an opportunity, or the permission to delve into this large topic $?^{11}$ Undoubtedly, there are countless examples of nudity, including the nude body of Christ Himself, or of Saint Sebastian, ${ }^{12}$ or of images of female saints whose body parts such as their breasts are cut off (Agatha of Sicily), which all is intended to heighten the sense of religious veneration, instead of providing visual materials for prurient interests.

As to be expected, there are many nudes in medieval art, whether in Romanesque sculptures, in biblical manuscripts containing the account of drunken Noah and his three sons, one of whom does not divert his eyes and gazes at his father's genitals, the presentation of nude Adam and Eve, nude infants who are baptized, and nude saints. ${ }^{13}$ None of those scenes convey a sense of sexual interest and do not need to be considered here. It is fully understandable, however, as Madeline H. Caviness underscores, that we need to distinguish between simple nudity and the stage of clothedness for specific semiotic reasons which have nothing to do with sexuality. ${ }^{14}$ However, she also alerts us to the pervasive ambiguity of the nude body which could convey either a religious message (Christ, the human soul, martyrs, medical analysis of the human body, etc.) or carry sexual connotations. ${ }^{15}$

Scores of medievalists and early modernists have already scoured the historical, legal, literary, and theological evidence regarding the history of sex, probably one of the strongest forces or drives in human life, both in the past and in the present, apart from anger, fear, hatred, and others. The Seven Deadly Sins include, for sure, lust as well, which underscores the fundamental significance which sex has had in all of human existence. "'Images of Lust," as Anthony Weir and James Jerman title their study of medieval sexual carvings, such as of sheela-na-gigs, are ever-present and only wait for their re-discovery by scholars no longer blinded by Protestant purism and old iconoclasm. ${ }^{17}$ However, to turn to the Old Testament again, sexuality remained of significant importance even within the

1994); cf. also the contributions Desire and Discipline: Sex and Sexuality in the Premodern West, ed. Konrad Eisenbichler and Jacqueline Murray (Toronto, Ont.: University of Toronto Press, 1996); Constructing Medieval Sexuality, ed. Karma Lochrie, Peggy McCracken, and James A Schultz. Medieval Culture, 11 (Minneapolis, MN: University of Minnesota Press, 1997); Discourses on Love, Marriage, and Transgression in Medieval and Early Modern Literature, ed. Albrecht Classen. Medieval and Renaissance Texts and Studies, 278 (Tempe, AZ: Arizona Center for Medieval and Renaissance Studies, 2004); Translating Desire in Medieval and Early Modern Literature, ed. Craig A. Berry and Heather Richardson Hayton. Medieval and Renaissance Texts and Studies, 294 (Tempe, AZ: Arizona Center for Medieval and Renaissance Studies, 2005)

10. On Love: A Selection of Works of Hugh, Adam, Achard, Richard, and Godfrey of St Victor, ed. Hugh Feiss OSB. Victorine Texts in Translation, 2 (Turnhout: Brepols, 2011).

11. For some preliminary investigations, see Bartz, Karnein, and Lange, Liebesfreuden im Mittelalter (see note 5).

12. For a large number of relevant images, see https://www.pinterest.com/davy_goedertier/sint-sebastiaan-2armen-omhoog/?lp=true (last accessed on Dec. 17, 2017).

13. The Meanings of Nudity in Medieval Art, ed. Sherry C M Lindquist (Farnham, Surrey, and Burlington, VT: Ashgate, 2012). As to Noah and Ham, see Madeline H. Caviness, "A Son's Gaze on Noah: Case or Cause of Viriliphobia?," ibid., 103-48.

14. Madeline H. Caviness, "Epilogue," The Meanings of Nudity in Medieval Art (see note 13), 319-36.

15. Madeline H. Caviness, "Epilogue," The Meanings of Nudity in Medieval Art (see note 13), 330-31.

16. Sin in Medieval and Early Modern Culture: The Tradition of the Seven Deadly Sins, ed. Richard Newhauser and Susan J. Ridyard (Woodbridge: York Medieval Press, 2012); Virginia Langum, Medicine and the Seven Deadly Sins in Late Medieval Literature and Culture. The New Middle Ages (Basingstoke: Palgrave Macmillan, 2016); Dante and the Seven Deadly Sins: Twelve Literary and Historical Essays, ed. John C. Barnes and Daragh O'Connell. Publications of the UCD Foundation for Italian Studies (Dublin: Four Courts Press, 2017).

17. Anthony Weir and James Jerman, Images of Lust: Sexual Carvings on Medieval Churches (London and New York: Routledge, 1986). Recently, Marian Bleeke, “'Hag of the Castle:' Women, Family, and Community in Later Medieval Ireland," Different Visions: A Journal of New Perspectives on Medieval Art 5 (2014; online at: http://differentvisions.org/issue-five/): 1-25, argues that the Sheela-na-gigs would have to be read as signs of female reproductive power: "The stories of Sheela that resembled these tales of Grace and Nuala would have tied the sculptures that bear her name into this tradition of family founding, castle-buildings, self-assertive, and so self-displaying women. Such tales would have put the issues of women, family, and power discussed above for medieval Ireland together in a different way, as they would have been stories of a woman who escaped the enclosure of a family castle to become a castle-builder herself and to become famous - or really infamous - not as a protected wife or daughter, but instead as a powerful mother" (20).

International Journal of History and Cultural Studies (IJHCS)

Page $\mid 3$ 
theological domain and surfaces over and over again in the various books contained in this massive sacred text. The Song of Songs, also the Fifth book of Wisdom in the Old Testament of the Christian Bible from sometime around the middle of the last millennium prior to the Common Era, provides most vivid examples for this phenomenon:

Let him kiss me with the kisses of his mouth-

for your love is more delightful than wine.

3 Pleasing is the fragrance of your perfumes;

your name is like perfume poured out.

No wonder the young women love you!

4 Take me away with you-let us hurry!

Let the king bring me into his chambers (1). ${ }^{18}$

Subsequently, we find many passages that would strike even us today as rather bold in their strongly erotic presentation:

While the king was at his table,

my perfume spread its fragrance.

13 My beloved is to me a sachet of myrrh

resting between my breasts.

14 My beloved is to me a cluster of henna blossoms

from the vineyards of En Gedi. ${ }^{19}$

On this basis we can address more poignantly the actual topic of this paper, sex in medieval art (or visual representation), because the explicit address in these poems was not lost to subsequent readers, whether during late antiquity or the medieval period. Sex has always been on the mind of people, both in the Middle Ages and today, as countless comments by St. Augustine, Anselm of Canterbury, Thomas of Aquinas, or any other major or minor theologians confirm. ${ }^{20}$ Sex holds sway both over the two genders, and over the members of the clergy of every religious denomination, being constantly evaluated as a danger for the human soul because of its almost irresistible lure, which again was certainly interpreted as most negative. Its manifestation can be found everywhere in literary, artistic, musical documents, but then also in political, religious, and philosophical narratives, whether with approval or disapproval. While it might hold true that medieval art was less permissive than medieval literature in that regard, much depends on the perspective and the selection of objects under investigation. Studying art in medieval churches, for instance, would mostly result empty-handed because medieval stained class windows, sculptures, altar pieces, and other art objects served religious purposes and were manifestly not concerned with sex, which was viewed as sinful at any rate, whether practiced within marriage or not.

Such a global perspective can be regarded as generally true, but a closer analysis based on a more specific perspective allows us to gain a more discriminating perspective, as was powerfully illustrated by an exhibition at the Helms-Museum in Hamburg, Germany, in 2004, and at numerous other

18. https://www.biblegateway.com/passage/?search=Song\%20of\%20Songs\%201. See also The Song of Songs: A New Translation and Interpretation by Marcia Falk (1982; San Francisco: HarperCollins, 1990). For commentary, see Roland E. Murphy, The Song of Songs: A Commentary on the Book of Canticles or the Song of Songs, ed. S. Dean McBride. Hermeneia - Critical and Historical Commentary on the Bible (Minneapolis, MN: Fortress Press, 1990); David H. Jensen, "The Bible and Sex," The Embrace of Eros: Bodies, Desires, and Sexuality in Christianity, ed. Margaret D. Kamitsuka (Minneapolis, MN: Fortress, Press, 2010), 15-31; Jr. Gianni Barber, Song of Songs: A Close Reading, trans. Michael Tait. Supplements to Vetus Testamentum, 144 (Boston: Brill, 2011).

19. Thomas M. Horner, Sex in the Bible (Rutland: Tuttle, 1974); J. Harold Ellens, Sex in the Bible: A New Consideration (Westport, CT: Praeger, 2006); Calum M. Carmichael, Sex and Religion in the Bible (New Haven, CT: Yale University Press, 2010).

20. See, for example, Alan G. Soble, "Correcting Some Misconceptions about St. Augustine's Sex Life," Journal of the History of Sexuality 11.4 (Oct., 2002): 545-69; Love, Sex and Marriage in the Middle Ages: A Sourcebook, ed. Conor McCarthy (London and New York: Routledge, 2004); The Embrace of Eros: Bodies, Desires, and Sexuality in Christianity, ed. Margaret D. Kamitsuka (see note 18). 
locations in the following years. ${ }^{21}$ The objects presented even included a dildo and manuscripts with specific scenes depicting sexual situations, such as the Li livres dou Santé by Aldobrundino da Siena from the late thirteenth century. The artist made great efforts to present a couple lying in bed together, involved in copulation, with her virtually on top of him, which would have been regarded as sinful by the Catholic Church. ${ }^{22}$ Would we then be justified to agree with famous Eduard Fuchs, who formulated in 1922 ,

Diese allgemeine Unmäßigkeit im Essen und Trinken war ein Hauptnährboden für den skatologischen Witz. Denn daß die Verdauung prompt vonstatten ging, war bei der Dauerbeschäftigung mit Fressen und Saufen das wichtigste Erfordernis . . . . Mit derselben Derbheit und demselben Unmaße wurde im Mittelalter der Wollust gefrönt. ${ }^{23}$

[This general immoderation in eating and drinking was one of the main sources for the scatological joke. Insofar as digestion sets in promptly, this was the central requirement for the constant occupation with excessive eating and drinking. . . People in the Middle Ages were also obsessed with sexual lust to the same degree of crudeness and excessiveness as in the other areas.]

Such a value judgment mostly disregards social and cultural reality in the Middle Ages and does not pay real attention to the actual documentary evidence. Nevertheless, the very opposite viewpoint concerning the overarchingly negative treatment of sexuality in medieval literature and the arts, for instance, also misses the mark.

Considering the biblical testimony, and keeping also in mind how much the Church Fathers and countless other religious authors from the early and high Middle Ages engaged with the implications of sex for their theological readings, we would be encouraged to consider how much this topic also transpired into visual representations at that time. While scholars have discussed the history of sexuality in many different fashions, applying a smattering of various methodological approaches, selective filters for their study of relevant objects and documents, and theoretical models, sex in medieval art by itself might seem too contradictory by itself to have attracted much attention. ${ }^{24}$ Nevertheless, it appears everywhere, especially when the least expected, such as in the borders of the famous Bayeux Tapestry (shortly after 1066), where the textile artists also included most explicit sexual poses, display of the male genitalia, and scenes presenting man and woman, both naked and sexually aroused, about to engage in copulation. Recent discussions of those textile images have offered a variety of interpretations, but there is no consensus. ${ }^{25}$

When Joyce E. Salisbury put together a collection of essays on sex in the Middle Ages, she invited literary and religious scholars, and historians to contribute, while art historians were not yet consulted. ${ }^{26}$ The Handbook of Medieval Sexuality contains numerous studies focused on sexuality as sin that had to be confessed, sex and canon law, gendered sex, chaste marriages, homosexuality and

21. 100.000 Jahre Sex: Über Liebe, Fruchtbarkeit und Wollust, ed. Vincent T. van Vilsteren and Rainer-Maria Weiss (Zwolle: Waanders Uitgevers, 2004).

22. 100.000 Jahre Sex (see note 21), 63. The image is contained in an initial for the letter 'c.' No other position but the 'missionary' one was acceptable for medieval theologians, such as twelfth-century Gratian. As Brundage, Law, Sex, and Christian Society (see note 4), observes, "Any Variants from this position, particularly the 'dog-style' (more canino) approach from the rear, or any position in which the woman was superior to the man, the decretists described as unnatural and reprehensible, even in the marriage bed" (286).

23. Eduard Fuchs, Geschichte der erotischen Kunst. Vol. 1:Das zeitgeschichtliche Problem (Munich: Albert Langen, [1922]. 159-60.

24. See, however, the excellent collection of data from many textual and visual sources by Peter Dinzelbacher, "Mittelalterliche Sexualität: Die Quellen," Privatisierung der Triebe? Sexualität in der Frühen Neuzeit, ed Daniela Erlach, Markus Reisenleitner, and Karl Vocelka. Frühneuzeit-Studien, 1 (Frankfurt a. M. and Berlin: Peter Lang, 1994), 47-110.

25. Pierre Bouet und François Neveux, Der Teppich von Bayeux: Ein mittelalterliches Meisterwerk. Übersetzt von Heike Rosbach und Hanne Henninger (2013; Darmstadt: Theiss, 2018), 144. They believe that the artist/s here followed Wace's Roman de Rou according to which the English soldiers devoted themselves to gluttony and orgies the evening before the battle against William the Conquerer in 1066, but this almost amounts to speculation, as they admit themselves.

26. Sex in the Middle Ages: A Book of Essays, ed. Joyce E. Salisbury. Garland Medieval Casebooks (New York and London: Garland, 1991). 
lesbianism, cross dressing, prostitution, contraception and abortion, castration, and then sex in the various cultural circles and literatures. ${ }^{27}$ Ruth Mazo Karras offered an in-depth analysis of the meaning of sex in medieval society at large, emphasizing above all the much closer association between sex and progeny, compared to the modern world. She also refers to curious images of naked people on the margin of the Bayeux Tapestry exhibiting their genitalia, even the erection of a penis, but she has no answer as to the true purpose of such depictions. ${ }^{28}$ The contributors to Medieval Sexuality examine the topic from a historical, political, religious, medical, and also literary perspective, and thereby ignore the world of the visual arts altogether, once again. ${ }^{29}$ It certainly deserves to be noted that the concept of sexuality is very much dependent on cultural, ethical, moral, and religious norms, leading to a form of conceptual construction, as recent critics have convincingly demonstrated. $^{30}$

By contrast, what matters truly centrally would be the realization that the sexual body figured much more prominently in medieval imagination than we would have normally assumed, both outside of the Church and also within. Focusing on medieval art, which mostly tended to be commissioned for religious purposes, represents the right challenge for our purpose and will allow us to uncover a significant level of meaning in medieval culture at large that has been ignored or simply bypassed too often. To repeat our basic thesis one more time, much of secular medieval literature is filled with implicit or explicit references to sexuality, sometimes even amounting to what we might call 'pornography' today, as difficult as this term might be to define it, especially in its historical context. ${ }^{31}$ Intriguingly, medieval art is also determined by explicit images of the sexualized human body, although we might have to look more at the margin and in the background of paintings and sculptures to discover the true extent of this topic, as Michael Camille has taught us already some years ago. He emphasizes, above all, "It was because sex was marginalized in medieval experience that it so often became an image on the edge." ${ }^{, 32}$ Over and over again, however, there is good reason to challenge such a view and to resist the temptation to read the world of medieval art in light of our modern assessment. Insofar as sex is so widely and easily available or accessible today, this does not mean, in a reverse historical logic, that it must have been repressed and covered up in the past. The images on the margins, such as in medieval illuminated manuscripts, certainly enjoyed a much higher status than we might imagine today, especially because most owners and readers of those manuscripts might not have had the necessary level of literacy to understand the written texts and focused more on the drolleries and other images on the sides. In other words, we have to pay close attention to the hermeneutic filters that we apply in our examination of the history of sex.

Peter Dinzelbacher judged the Middle Ages as a world in which sex was certainly practiced, but mostly hidden, very much in contrast to Greek and Roman antiquity, or the ancient Indian culture. As

27. Handbook of Medieval Sexuality, ed. Vern L. Bullough and James A. Brundage (New York and London: Garland, 1996).

28. Ruth Mazo Karras, Sexuality in Medieval Europe: Doing Unto Others (New York and London: Routledge, 2005), 14-15.

29. Medieval Sexuality: A Casebook, ed. April Harper and Caroline Proctor (New York and London: Routledge, 2008).

30. Constructing Medieval Sexuality, ed. Karma Lochrie, Peggy McCracken, and James A. Schultz. Medieval Culture, 11 (Minneaplois, MN, and London: University of Minnesota Press, 1997).

31. Ian Frederick Moulton, Before Pornography: Erotic Writing in Early Modern England (Oxford: Oxford University Press, 2004); Nicola McDonald, Medieval Obscenities (Woodbridge, Suffolk: York Medieval, 2006); Albrecht Classen, "Sexual Desire and Pornography: Literary Imagination in a Satirical Context: Gender Conflict, Sexual Identity, and Misogyny in 'Das Nonnenturnier',' Sexuality in the Middle Ages and Early Modern Times: New Approaches to a Fundamental Cultural-Historical and Literary-Anthropological Theme, ed. Albrecht Classen. Fundamentals of Medieval and Early Modern Culture, 3 (Berlin and New York: Walter de Gruyter, 2008), 649-90. See also Wolfram von Kossak and Stockhorst. "Sexuelles und wie es zu Wort kommt: Die Frage nach dem Obszönen in den Liedern Oswalds von Wolkenstein," Daphnis 28 (1999): 1-33, highlighting pornographic elements in early fifteenth-century poetry.

32. Michael Camille, Image on the Edge: The Margins of Medieval Art (London: Reaktion Books, 1992$), 40$. For a good critical assessment in light of new research, see now Laura Kendrick, "Making Sense of Marginalized Images in Manuscripts and Religious Architecture," A Companion to Medieval Art: Romanesque and Gothic in Northern Europe, ed. Conrad Rudolph. Blackwell Companions to Art History (Malden, MA, Oxford, and Chichester, UK: Blackwell, 2010), 274-94; here 289-90. 
he notes, the Catholic Church tried its hardest to repress sexuality in every possible form, which meant that artists could deal with sexual matter only if it was applied in an apotropaic or moralhortative manner. Drawing from global observations, he opines that most medieval men had little understanding of sexual intercourse and treated their partners mostly in a brutal, brutish, and altogether unsatisfactory fashion. Sex was regarded, as Dinzelbacher underscores, as something that people had to do, which took place quickly, and was regularly associated with a bad conscience. Peasants would not have had any idea of tenderness or foreplay, of women's need for their own sexual pleasure; knights would have bothered little about peasant women whom they freely raped. ${ }^{33}$ Again, this also seems to amount to a value judgment that needs to be carefully balanced with actual evidence.

Concomitantly, Dinzelbacher grants that a close reading of penitentiaries, for instance, would reveal the true extent to which people resorted to many different forms of sexual intercourse, even though they subsequently felt coerced to confess to their priest that they had sinned in that regard. We are thus told of oral and anal sex, and even of sex toys, whereas orgies were consistently condemned as heretical and devilish, something which only non-Christians might do and which hence would have to be regarded as despicable. ${ }^{34}$ However, the more individual writers condemned orgies, the more we are encouraged to consider that such form of sex might have transpired in secret after all. Or, to put it differently, such sharp criticism certainly reflects a certain dimension of sexual fantasy already at that time.

This leaves us with a considerable dilemma concerning sex in medieval art, that is, art which was mostly produced for public consumption and paid for by wealthy authority figures, often in the service of the Church. Consequently, at first sight the theme of sex does not seem to be easily visible, and if there are references to it, they quickly prove to be satirical, sarcastic, condemning, or hortative in nature, such as in the copper engravings by the so-called "Meister E.S. from the 1460s or 1470s. In his depiction of the 'Garden of Lust' (Liebesgarten), for instance, we are confronted synchronously with several scenes in one picture, in the background displaying an open field with a tournament taking place, while we see, in the lower part, couples enjoying their time together, all involved in erotic pursuits. One man touches his lady's breast, the other offers a goblet of wine, which also symbolizes his love wooing, while a third one is already leading his lady away, holding her by her arm, whereas she is lifting his coat and thus reveals his true nature as a fool.

The entire setting is derived from the concept as developed in the famous allegorical romance Roman de la rose, its first part having been composed by Guillaume de Lorris ca. 1230/40, the second by Jean de Meun in ca. 1270/80, which in turn was influenced by the concept of the hortus conclusus. While the Meister E.S. clearly intended to ridicule the world of secular love poetry and of courtly culture at large, and while Jean de Mean almost cynically undermined the ideal of courtly love as projected by Guillaume, the hortus conclusus constituted, of course, the location where the Virgin Mary topographically resides and often receives the unicorn, a symbol of Christ. ${ }^{35}$ Late medieval art knows of countless examples of the enclosed garden, which symbolizes both the most intimate religious

33. Peter Dinzelbacher, Lebenswelten des Mittelalters 1000-1500. Bachmanns Basiswissen, 1 (Badenweiler: Wissenschaftlicher Verlag Bachmann, 2010), 24-26. This is pretty much the same position as he had formulated in his article "Sexualität/Liebe: Mittelalter" (1993/2008; see note 2).

34. Dinzelbacher, Lebenswelten (see note 33), 28-30. See also Dinzelbacher, "Gruppensex im Untergrund: Chaotische Ketzer und kirchliche Keuschheit im Mittelalter," Sexuality in the Middle Ages (see note 31), 40528. As to the possibility to read some late medieval love songs as hidden allusions to oral sex, see Rasma LazdaCazers, "Oral Sex in Oswald von Wolkenstein's 'Es seusst dort her von orient' (K1. 20)," ibid., 579-98. As to the significant cultural information that can be drawn from penitentiaries, see Arnold Esch, Die Lebenswelt des europäischen Spätmittelalters: Kleine Schicksale selbst erzählt in Schreiben an den Papst (Munich: Beck, 2014); he deals, however, as far as we are concerned only with marriage problems and conflicts between people who are forced to marry or want to marry someone else than the one selected by the parents, 38-50.

35. Martin Warnke, Spätmittelalter und Frühe Neuzeit 1400-1750. Geschichte der deutschen Kunst, 2 (Munich: C. H. Beck, 1999), 221-23; Janez Höfler, Der Meister E. S: Ein Kapitel europäischer Kunst des 15. Jahrhunderts (Regensburg: Schnell \& Steiner, 2007); Holm Bevers, Der große Liebesgarten. Katalog, 30 (Frankfurt am Main: Kunsthandlung Helmut H. Rumbler, 1994); Markus Nass, Meister E. S.: Studien zu Werk und Wirkung. Europäische Hochschulschriften. Reihe 28, Kunstgeschichte, 220 (Frankfurt a. M., Berlin, et al.: Peter Lang, 1994). 
experience, that is, the Virgin's epiphany and the archangel's annunciation, and the locus of sexual seduction, as expressed, for instance, in the verse narrative by Dietrich von der Gletze, "The Belt" (late fourteenth century). ${ }^{36}$ The unicorn tapestries, "La Dame à la licorney" in the Musée de Cluny (formerly Musée de Cluny) from ca. 1500 offer a most telling example. ${ }^{37}$ The Meister E.S. explicitly projected a scene of fools, ridiculing those who dedicate themselves to a life of debaucheries, sexual pleasures, drinking, and courtly love. For him, the world was populated by fools, and sexuality profiled this lack of intelligence and rationality, as also greatly illustrated in the copper engraving "Fool and Naked Woman with Mirror" from ca. $1460 . .^{38}$ Late medieval satirical literature, which tended to target peasants as fools, such as Heinrich Wittenwiler's Ring (ca. 1400), confirms this impression. ${ }^{39}$ Altogether, however, the artists made a definite effort to engage with sexuality and depicted what people lusted after, particularly because this master intended to ridicule basic human instincts and desires, especially aiming for sex.

As much as the engraving conveys a sense of joy and happiness, there is also a dark side of definite sarcasm concerning the pursuit of sexual joys which exposes everyone in this scene as morally unstable or as a fool. ${ }^{40}$ Both here and in countless other examples, as we will see below, there is a remarkable perception of the individual's weakness in handling the sexual force in a reasonable manner, both according to clerical principles and public mores. It does not come as a surprise that the theme of sex consequently entered medieval art much more than we have previously assumed, certainly within the world of secular society, but then also within the Church, as we will observe below.

Margaret R. Miles, for instance, argued that the female breast was not perceived in any sexualized manner until the sixteenth century because its function primarily for lactation, especially in the case of breast-feeding the Christ child, entirely dominated medieval art. "The religious breast was neither owned nor constructed by women, but served the symbolic repertoire of the Christian church. ${ }^{41}$ As Miles suggests, the breast's eroticization occurred not before the early modern age, often associated with the public display of the image of the witch with her exposed breast, as massive amounts of printed documents confirm. However, in that case, the female breast normally appears as shriveled and unappealing, not at all erotic in its exposure. Otherwise, however, corresponding comments by the mystic Mechthild of Magdeburg would confirm this positive observation of the erotic features of the breast, but only in a very specific context. ${ }^{42}$ Similarly, in Fernando de Rojas's famous Celestina

36. Erotic Tales of Medieval Germany, selected and trans. by Albrecht Classen. Sec. ed. Medieval and Renaissance Texts and Studies, 328 (2007; Tempe, AZ: Arizona Center for Medieval and Renaissance Studies, 2009), 19-28. For the symbolism of the enclosed garden, see Barbara Baert, Late Medieval Enclosed Gardens of the Low Countries: Contributions to Gender and Artistic Expression. Studies in Iconology, 2 (Leuven, Paris, et al.: Peeters, 2014); for the Marian iconography within the context of the garden typology, see Lasse Hodne, The Virginity of the Virgin: A Study in Marian Iconography. Palindromos, 2 (Rome: Scienze e Lettere, 2012).

37. For a good introduction of the tapestry in Paris, with excellent digital images, see https://en.wikipedia.org/wiki/The_Lady_and_the_Unicorn (last accessed on Dec. 13, 2017).

38. Kupferstich-Kabinett, Staatliche Kunstsammlung Dresden; https://i.pinimg.com/736x/29/cf/3e/29cf3ee8e3 fa35f1a7236fda2b6d98f7--coat-of-arms-th-century.jpg; for a contrast, however, see the copper engraving, "Liebespaar auf der Gartenbank" (amorous couple on a garden bench), where foolishness is not at all the thematic focus. The young man certainly touches her breast, but both young people are fully clothed in a noble fashion and do not display any negative features. She seems to demur somewhat, defensively pushing him back with her left hand, but possibly inviting him, after all, to go further, as her upheld right hand might signal; http://deacademic.com/pictures/dewiki/76/Liebespaar_auf_der_Gartenbank.jpg. I would also argue that the rapier hanging off his belt does not necessarily carry a sexual symbolism.

39. Heinrich Wittenwiler, Der Ring: Text - Übersetzung - Kommentar. Nach der Münchener Handschrift herausgegeben, übersetzt und erläutert von Werner Röcke unter Mitarbeit von Annika Goldenbaum (Berlin and Boston: Walter de Gruyter, 2012); for the most comprehensive analysis, emphasizing the allegorical dimension of Wittenwiler's work, see Eckart Conrad Lutz, Spiritualis fornicatio: Heinrich Wittenwiler, seine Welt und sein 'Ring'. Konstanzer Geschichts- und Rechtsquellen, 32 (Sigmaringen: J. Thorbecke Verlag, 1990).

40. Keith P. Moxey, "Master E.S. and the Foll of Love," Simiolus 11 (1980): 125-48.

41. Margaret R. Miles, A Complex Delight: The Secularization of the Breast 1350-1750 (Berkeley, Los Angeles, and London: University of California Press, 2008), 138.

42. Miles, A Complex Delight (see note 41), 111.Mechthild of Magdeburg, The Flowing Light of the Godhead. Trans. and intro. by Frank Tobin (New York and Mahwah, NJ: Paulist Press, 1998), no. 22, p. 51-52. 
(printed first in 1499), the female breast is definitely sexually connoted, as the protagonist herself confirms when she inspects another woman's body. ${ }^{43}$ Nevertheless, long before that age, medieval artists such as the Meister E.S. focused also on the female breast and depicted it as a highly erotic object for men's pleasure. There are countless images showing us the hybrid creature Melusine, half human and half a snake, and most of the time her breasts are exposed, viewed at by her voyeuristic husband Reymund and hence also the contemporary audience. ${ }^{44}$

A woodcut from 1477 contained in a printed version produced by Heinrich Knoblochtzer in Strasbourg, demonstrates clearly the great erotic function of her breasts since she tries to cover the right one with one hand, but the viewer is still allowed to gaze at the left one. The erotic dimension is even heightened by her seeming sense of embarrassment about her exposed body. ${ }^{45}$ Similar scenes appear in a manuscript containing Le Roman de Girart de Nevers (ca. 1460), in a manuscript with Roman de la Violette, and in a Book of Hours from ca. 1510. ${ }^{46}$ Miniatures illustrating Guido da Columna's Historia Troiana, created by Martinus Opifex ca. 1450, present unabashedly various scenes of lovers together in bed, fondling each other, with the man focusing on her breasts, and engaging in copulation. ${ }^{47}$ And the artist who created an image of a married couple embracing and fondling each other in the Tacuinum sanitatis in medicina (ca. 1390) left no doubt about the husband's delight in playing with his wife's breast. ${ }^{48}$ In short, much depends on the context of the literary and the artistic genre, but to claim that medieval artists or writers simply ignored the female breast as unerotic, not to speak of the vulva, can simply not be upheld. In Fernando de Roja's famous $L a$ Celestina (1499), Calisto is virtually inebriated with Melibea's breast: "If only I could describe what her round firm breasts are like!"49 This also applies to male genitalia, which are often portrayed already in early medieval sculptures, such as in capitals and corbels, mostly in an apotropaic sense, but there are also enough medieval images that convey a rather positive evaluation of all human sex organs. There are countless nude mermaids and sirens, and they all convey a sense of their sexual attractiveness, a danger for men's souls and a symbol of the sin of luxuria, and yet many times rather erotically highly appealing both for the medieval and the modern viewer. ${ }^{50}$

After all, the topic of sex has always caused much excitement and distress, fear and desire at the same time, especially in Christian teaching because all intercourse has been associated with physical excitement and hence with sinfulness, as Huguccio of Pisa (d. 1210) remarked: "Notandum quod uir commiscetur uoxori quatuor de causis, scilicet cause prolis, causa reddendi debitum, causa incontientie, causa ex saturande libidinis uel explende uoluptatis" (Let's note that man sleeps with his wife for four reasons, that is, to create progeny, to pay his debt to her, because he cannot contain

43. Fernando de Rojas, Celestina, trans. with an afterword by Peter Bush. Intro. by Juan Goytisolo (London: Penguin, 2009), 85.

44. Albrecht Classen, "The Melusine Figure in Fifteenth- and Sixteenth-Century German Literature and Art: Cultural-Historical Information Within the Pictorial Program. With a Discussion of the MelusineLüsterweibchen Connection," Melusine's Footprint: Tracing the Legacy of a Medieval Myth, ed. Misty Urban, Deva F. Kemmis, and Melissa Ridley Elmes. Explorations in Medieval Culture, 4 (Leiden and Boston: Brill, 2017), 74-94.

45. Marion Hanke and Ina Nettekoven, Heroies and Heroines: "Volksbücher”, Prose Novels in Late Medieval Society. Catalogue, 13 (Stalden, Switzerland: Dr. Jörn Günther Rare Books, 2017), 45. Nanette Salomon, "Making a World of Difference: Gender, Asymmetry, and the Greek Nude," Naked Truths: Women, Sexuality, and Gender in Classical Art and Archaeology, ed. Ann Olga Koloski-Ostrow and Claire L. Lyons (London and New York: Routledge, 1997), 197-219

46. Diane Wolfthal, "Sin or Sexual Pleasure? A Little-Known Nude Bather in a Flemish Book of Hours," The Meanings of Nudity in Medieval Art (see note 13), 279-97; here 285, and notes 22-24.

47. Vienna, Österreichische Nationalbibliothek, Cod. 2773, fol. 18r and 18v; here drawing from Bartz, Karnein, and Lange, Liebesfreuden im Mittelalter (see note 5), p. 45.

48. Paris, Bibliothèque Nationale, n.a. lat. 1673, fol. 100v; here drawn from Bartz, Karnein, and Lange, Liebesfreuden im Mittelalter (see note 5), 76.

49. Fernando de Rojas, Celestina, trans. with an afterword by Peter Bush, intro. by Juan Goytisolo (London: Penguin, 2009), 9.

50. Weir and Jerman, Images of Lust (see note 17), 48-57. 
himself, and because he needs to release his libido or exhaust his voluptuousness $)^{51}$ The purpose of this paper, however, cannot be to review the entire history of sexuality in the Middle Ages once again. Instead, as already indicated with the case of the Meister E.S., I want to probe more in detail what types of art work from that time period have come down to us in which sexuality is a major concern. How have the various medieval artists depicted the sexualized human body and evaluated this topic altogether. After all, the contemporary secular literature is simply riddled with reference to sex, both in the Carmina Burana (ca. 1220-1240) and in vernacular love poetry (trobadour, trouvère poetry, Minnesang, poetry of the stil dolce nuovo, etc.). ${ }^{52}$ Sexual metaphors emerge everywhere, and laughter about highly erotic scenes, such as in the verse narratives of the fabliaux, tales, novelle, or maeren, erupts all the time. ${ }^{53}$

On the one hand, I want to interrogate some manuscript illustrations from the early to the late Middle Ages; on the other, I intend to examine corbels and misericords, and furthermore additional examples of sex as treated in paintings and sculptures. I cannot aim for a complete coverage, but through a selective analysis I hope to demystify many perceptions about the medieval world of art and demonstrate how much the human body in its sexual connotation appears to have been of significant interest, either being rejected for religious reasons, or as an object of titillation, attraction, and excitement. $^{54}$

The power of sexual temptation has always been with us, and the more the Christian clergy tried to distance itself from sexual experiences by way of the oath of celibacy and the enclosure of monks and nuns in the monasteries and convents, the more the attraction grew in intensity, as many theological writers confirmed through their hortative, critical, or condemning voices. For instance, we would have a hard time fully comprehending medieval sermon literature if we ignored the constant warnings about sexual transgressions in a myriad of fashions. ${ }^{55}$ Similarly, late medieval verse narratives are constantly concerned with lecherous priests, monks, and other clergy, especially in Italian, French, English, and German literature. ${ }^{56}$ However, can we also detect a discourse on sex in medieval art? And was there a difference in attitudes toward sex in Christian and Jewish art? Although here is not the room to investigate this additional perspective, it is worth noting that Sarit Shalev-Eyni was recently able to confirm a much stronger positive approach to human sexuality, the female breast, and the value of sexual potency also in old age (motif of the 'fountain of youth,' see below) in medieval

51. Quoted from Brundage, Law, Sex, and Christian Society (see note 4), 281; Dinzelbacher, Lebenswelten (see note 33), 30 .

52. Stefan Zeyen, ...daz tet der liebe dorn: Erotische Metaphorik in der deutschsprachigen Lyrik des 12.-14. Jahrhunderts. Item Mediävistische Studien, 5 (Essen: Item-Verlag, 1996); Gaby Herchert, "Acker mir mein bestes Feld": Untersuchungen zu erotischen Liederbuchliedern des späten Mittelalters (Münster and New York: Waxmann, 1996); see also Patricia Simons, The Sex of Men in Premodern Europe: A Cultural History (Cambridge and New York: Cambridge University Press, 2011).

53. Mareike von Müller, Schwarze Komik: Narrative Sinnirritation zwischen Märe und Schwank. Studien zur historischen Poetik, 24 (Heidelberg: Universitätsverlag Winter, 2017); Hans Rudolf Velten, Scurrilitas: Das Lachen, die Komik und der Körper in Literatur und Kultur des Spätmittelalters und der Frühen Neuzeit (Tübingen: Narr Francke Attempto Verlag, 2017); Sebastian Coxon, Laughter and Narrative in the Later Middle Ages: German Comic Tales 1350-1525 (London: Modern Humanities Research Association and Maney Publishing, 2008).

54. For numerous additional examples, see Bartz, Karnein, and Lange, Liebesfreuden im Mittelalter (see note 5). 55. See, for instance, Siegfried Wenzel, The Art of Preaching: Five Medieval Texts \& Translations (Washington, DC: The Catholic University of America Press, 2013); see the section on "De Luxuria" in the Fasciculum Morum: A Fourteenth-Century Preacher's Handbook, ed. and trans. by Siegfried Wenzel (University Park, PA, and London: The Pennsylvania State University Press, 1989), 648-701.

56. Birgit Beine, Der Wolf in der Kutte: Geistliche in den Mären des deutschen Mittelalters. Braunschweiger Beiträge zur deutschen Sprache und Literatur, 2 (Bielefeld: Verlag für Regionalgeschichte, 1999); see also Jennifer D. Thibodeaux, "The Sexual Lives of Medieval Norman Clerics: A New Perspective on Clerical Sexuality," Sexuality in the Middle Ages (see note 31), 471-83; cf. eadem, The Manly Priest: Clerical Celibacy, Masculinity, and Reform in England and Normandy, 1066-1300. The Middle Ages Series (Philadelphia, PA: University of Pennsylvania Press, 2015). 
Jewish culture. According to Jewish belief, marriage was of supreme importance, and husbands were obligated to satisfy their wives sexual desires. ${ }^{57}$

We come across a fascinating example already in the early Middle Ages pertaining to St. Benedict of Nursia (d. ca. 555/560). Although he was later to enjoy universal respect and admiration, throughout his life he also had to face envious slanderers and critics, as we can read in the second book of Gregory the Great's Dialogi (Libri IV dialogorum de vita et miraculis italicorum et de aeternitate animarum, from ca. 593-594). When Benedict attracted an increasing number of disciples, he moved to Subiaco south of Rome where he founded a new community center. However, there he was attacked by sexual lust and decided to squash it by hurting himself, hurling his body into thorny bushes and nettles, which made his feelings of lust disappear immediately and for good. ${ }^{58}$ In fact, throughout the history of the Christian Church, there was great fear of sexual temptations, which explains why virtually all depictions of hell, especially in the late Middle Ages, teem with scenes where individual sinners are punished on the responsible body parts, i.e., their genitals, with which they had committed their transgression, such as in the most impressive frescoes in the Collegiate Church of San Gimigniano (fourteenth century). ${ }^{59}$ As horrifying as the punishments appear to be, as impressive the art work proves to be, giving the viewer stark images of how evil people could be hurt when in the power of the devils. The work was completed in 1393 by Taddeo di Bartolo, one of the foremost Sienese painters of the fourteenth century, and conveys specifically what the consequences of adulterous sexuality and of other deadly sins would be. Warning images like these have, however, always had another side, allowing the viewer to gaze at the exposed body and enjoy, despite all horror, visual excitement. This also applies already to the early Christian Church, which thus allows us to return to the case of Benedict, though now from a different perspective.

A worldly priest called Florentinus (or Florentius) serving in a close-by church felt jealousy about Benedict's great popularity, and tried to assassinate him, first by sending a poisoned loaf of bread, which failed because the saint immediately saw through the deception and ordered a raven to carry away the bread. Next, Florentinus sent a group of young naked women to the monastic garden who performed titillating dances in order to lure the monks from their cells. Benedict noticed the new danger for himself and his community, however, which could have badly undermined his religious reputation, and decided to move away from that location and to found his final resting place, the famous Montecassino.

We are told about the entire scene in the Vita beati Benedicti abbatis in veteri lege figurata et per doctores nove legis luculenter approbata composed by Jean de Stavelot, who composed this book in Liège in 1432. In order to drive home the critical moment and to convey a deft lesson, the scene was beautifully illustrated, and which today allows us to gain an excellent insight into the constant struggle which members of the Catholic clergy had to go through vis-à-vis sexuality and their own bodily desires. Florentinus knew what he was doing to seduce Benedict's brethren, although it remains unclear where he got those girls from and why they obeyed his command to go to Benedict's community. If the saint would have failed, we would have to assume that the disciples would have come out of their cells and would have joined the sexual frolicking. But Benedict, here already identified as a saint through the halo above his head, stepped in and apparently chased the women away.

57. Sarit Shalev-Eyni, "The Bared Breast in Medieval Ashkenazi Illumination: Cultural Connotations in a Heterogeneous Society," Different Visions: A Journal of New Perspectives on Medieval Art 5 (2014; online at: http://differentvisions.org/issue-five/): 1-39. As to the scriptural regulations, see Nashim Mishnah, "Ketuboth 6:6," The Mishnah, trans. Herbert Danby (Oxford: Oxford University Press, 1950), 252; Daniel Boyarin, Carnal Israel: Reading Sex in Talmudic Culture (Berkeley: University of California Press, 1993).

58. Saint Benedict: A Translation of Gregory the Great's Life of Benedict, trans. Justin MacCann. Living Flame Series, 10 (Dublin: Carmelite Centre of Spirituality, 1980); William Junker, "Benedict Among the Brambles: A Revisionary Reading of Gregory the Great's "Life of Benedict," Religion \& Literature 45.3 (2013): 1-24.

59. Franz Hofmann, Der Freskenzyklus des Neuen Testaments in der Collegiata von San Gimignano: ein herausragendes Beispiel italienischer Wandmalerei zur Mitte des Trecento. Beiträge zur Kunstwissenschaft, 65 (Munich: Scaneg, 1995); Griffith Mann, "From Creation to the End of Time: The Nave Frescoes of San Gimignano's Collegiata and the Structure of Civic Devotion,” Ph.D. Johns Hopkins University, Baltimore, 2002; La Collegiata di San Gimignano, ed. Alessandro Bagnoli. Text by Ilaria Albizzi. Itinerari e proposte, 12 (Siena: Protagon Ed., 2009). 
A number of pictorial elements deserve to be highlighted which underscore the sexual theme in this manuscript illustration. ${ }^{60}$ The artist paid great attention to the women's sexual organs, including their vaginas. Almost all of them have long blond hair, and they dance in a circle, holding hands, except for one who has raised her left hand as if to invite Benedict to join them since there is room for him in the circle. Considering the poor saint's posture and ardent gaze upon the naked female bodies, we gain the clear impression how much self-control and discipline was necessary for him to resist the enormous temptation to participate in an orgy, which Florentinus, standing on the top left behind the circle of women, apparently wants him to enjoy.

Just as in the case of the Meister E. S., the medieval artist had no inhibition to depict seductive naked women; however, his concern was not pornography, but to teach a religious lesson, presenting to us the saint in a highly tempting situation but strong enough to constrain himself and not to fall to the seduction. ${ }^{61}$ A true saint proves him- or herself by resisting even the most attractive seduction attempt. As the artist implied, most male viewers would have failed to hold back and would have accepted this free offer, although we might even have to assume that these women were nothing but prostitutes hired by Florentinus to expose Benedict and his disciples as hypocrites and as ordinary men who only pretended to live a pious life in their community.

However, fifteenth-century book illustrations often included highly sexual themes, not at all critical of sexuality and the company of men and women in a private setting, such as a bathhouse where they could easily enjoy each other. In those scenes, hence, the criticism against sexuality, as commonly voiced by representatives of the Church, simply fell away and gave way to common approval of the erotic topics dealt with by the artist.

This is wonderfully illustrated by the miniature in a manuscript created for the Duke of Burgundy from ca. 1470 which appears to be in private property today and has not been further identified so far. Here we see a couple in a rather explicit situation, though both are attired in courtly fashion typical of the time. However, she is holding a large chest in front of her, which he is trying to open with a humongous key which he is holding with his right hand and which can easily be identified as an extension of his erect penis. His long coat is opening below his hip, showing that he is not dressed underneath. He wears only a pair of simple slippers, as if he had just gotten out of bed. The lady seems to be welcoming his approach, raising her right hand with which she is almost touching his left hand. She is fully dressed, but the key hole can easily be interpreted as a metaphoric image of her pudenda. In several parchment scrolls above their heads we read that she is encouraging him to unlock her chest, which pleases him mightily. Undoubtedly, the scene suggests sexual foreplay and hence a couple happily preparing themselves for a night of pleasure. Similar scenes appear in the same manuscript, each time predicated on a courtly scene, but all easily identifiable as metaphors of sexual operations. ${ }^{62}$

In the late Middle Ages we also encounter numerous pictorial themes dealing with the Fountain of Youth. The so-called 'Meister mit den Bandrollen' (Master of the Banderoles) created one impressive example, today held in the Albertina, Vienna. ${ }^{63}$ The basic idea is easy to understand since the artist deals with the ancient myth that a special kind of fountain might restore people's youth. Here, the massive construction of the fountain is situated in a park-like setting where many different

60. Chantilly, Musé Condé, formerly ms. 1401, today Ms. 738; see Benedictus: Eine Kulturgeschichte des Abendlandes. Das Leben und die Regel des heiligen Benedikt, ed. Pieter Batselier (Geneva: Weber, 1980), 19.

61. I have examined this illustration already once at greater length in Albrecht Classen, Sex im Mittelalter: Die andere Seite einer idealisierten Vergangenheit. Literatur und Sexualität (Badenweiler: Wissenschaftlicher Verlag Bachmann, 2011), 18-20.

62. Classen, Sex im Mittelalter (see note 61); for images of this manuscript, see online at https://i.pinimg.com/23 6x/a6/04/3d/a6043d0cb3563558f7bac3b3ba0b5f51--quidam-the-long.jpg

63. Max Lehrs, Der Meister mit den Bandrollen: ein Beitrag zur Geschichte des ältesten Kupferstiches in Deutschland (Dresden: Hoffmann, 1886); for a b/w reproduction online, see https://www.akg-images.com /Docs/AKG/Media/TR3_WATERMARKED/1/b/0/1/AKG30887.jpg; for other images by this Meister in the Albertina, see https://www.google.com/search?q=Albertina,+Meister+mit+ den+Bandrollen \&rlz=1C1GGRV _enUS756US757\&tbm=isch\&tbo=u\&source=univ\&sa=X\&ved=0ahUKEwja7_SU0ozYAhUVz2MKHRWhBp kQsAQIJg\&biw=1276\&bih=572. For a large printed reproduction, see Fuchs, Geschichte der erotischen Kunst (see note 23), insert between p. 160 and 161. 
representatives of courtly society enjoy their company. On the left side, old men carry their old wives to the fountain and throw them into the water, which mysteriously transforms them into young adults. The viewer's gaze is focused on the young nude people standing in the water and playing with each others' bodies or simply enjoying their re-established youthfulness. While the men wear some kind of loin cloth, the women are completely naked. In fact, one of the men touches his lady's pudenda, while she holds up her right breast, inviting him to enjoy it for his sexual pleasure. One woman on the left of them holds her right hand in front of her vagina, but it is still clearly visible, while the lady to the right does not care at all and displays her full nudity. Outside of the fountain, fully clothed couples are engaged in erotic embraces and touches. Sexuality proves to be of great value, and the viewers are fully invited to enjoy all sexual delights available, here by means of the erotic gaze, but then, in real terms as well in their private lives. ${ }^{64}$

Many other artists resorted to the same motif, the 'Fountain of Youth,' such as the creator of the frescoes in the Castello di Manta in the western part of the Piedmont (end of the fifteenth century), that is, in the "Sala baronale," painted by a student of Giacomo Jaquerio. ${ }^{65}$ And each time we are regaled with positive images of human sexuality, especially within the context of courtly culture. Many other late medieval frescoes both in aristocratic castles and in urban houses include similarly explicit scenes, which defy most of our general assumptions about the treatment of sexuality in the pre-modern world. Numerous artists presented scenes in late medieval bath houses where men and women freely touch each other and enjoy sexual lust without inhibition. ${ }^{66}$ One of the most famous examples would be a scene in a Burgundian bathhouse created by Anthony of Burgundy in an illustration for the Faits et dits mémorables des romains, a French translation of Valerius Maximus's Facta et dicta memorabilia, created around 1470 and today held at the Staatsbibliothek zu Berlin. ${ }^{67}$ While the emperor stands behind the door and views the group of nude people with amazement and curiosity, the men and women fondle each other without any inhibition. Various interpretations are certainly possible here, whether the illustration served as a moral warning against lewdness in public baths, against the visit of a brothel, or as an advice for rulers not to submit to lustfulness and sexuality. We can affirm here that the naked, sexualized body was of great importance for the artist and his patron, whatever the motivation behind the image might have been.

All this does not necessarily mean that the sexualized body or the enjoyment of sex was uniformly evaluated as positive, as we find numerous examples of satire, irony, condemnation, moral complaints about laxity and even depravity, as naturally and consistently voiced by clerics, ${ }^{68}$ but the wide-spread presentation of such themes in late medieval art underscores impressively that the Church was not at all the supreme authority in that regard, as much as it tried to assume such a position by means of the catalogue of sins and the threat of punishments in the afterlife. ${ }^{69}$ Further, the late Middle Ages witnessed the dramatic increase in bathing cultures, as demonstrated by numerous visual depictions both in manuscripts (Konrad Kyeser, Bellifortis, ca. $1420,{ }^{70}$ the Hausbuch in the collection of Burg

64. Stefanie Knöll, "Vom Jungbrunnen zur Jungmühle: Phantasien von der ewigen Jugend," Altersphantasien im Mittelalter und in der Frühen Neuzeit, ed. Jürgen Wiener. Studia humaniora, 49 (Düsseldorf: düsseldorf university press, 2016), 135-60.

65. Anna Rapp, "Der Jungbrunnen in Literatur und bildender Kunst des Mittelalters," Ph.D. Zürich 1976; Steffi Roettgen, Wandmalerei der Frührenaissance in Italien. Vol. 1: Anfänge und Entfaltung 1400 - 1470 (Munich: Hirmer, 1996).

66. For many examples, though not well documented, see Hans Peter Duerr, Nacktheit und Scham: Der Mythos vom Zivilisationsprozess (Frankfurt a. M.: Suhrkamp, 1988).

67. Robert Büchner, Im städtischen Bad vor 500 Jahren: Badhaus, Bader und Badegäste im alten Tirol (Vienna: Böhlau Wien, 2016), 43-45. For a digitized image, see http://www.fine-art-images.net/en/showIMG_40110. html.

68. See the contributions to The Embrace of Eros (see note 18). As the individual contributors make abundantly clear, there is a vast library dedicated to the question of how representatives of the Church viewed sexuality throughout the ages.

69. Again, see the detailed discussion of this complex by James A. Brundage, Law, Sex, and Christian Society (see note 4).

70. See the digitized manuscript at http://daten.digitale-sammlungen.de/ db/0009/bsb00090291/images/ index.html?fip=193.174.98.30\&seite=76\&pdfseitex=. For Kyeser, see Konrad Kyeser: Bellifortis; $\mathrm{Clm}$ 30150, ed. Ulrich Montag. Patrimonia, 137 (Munich: Bayerische Staatsbibliothek, 2000); see also the convenient article online at http://de.wikipedia.org/wiki/Konrad_Kyeser (both last accessed on April 15, 2015). Both humanists 
Wolfegg, ca. 1480, simply known as Hausbuch Wolfegg $^{71}$ ) and architectural designs. ${ }^{72}$ Moreover, whether for moral teachings or out of a devious delight in the same matter, sexual objects, activities, or themes also entered countless art works commissioned by members of the Church, whether we think of illustrated manuscripts or even liturgical objects. ${ }^{73}$ Late medieval satirical writers such as Boccaccio, Chaucer, Sacchetti, or Kaufringer had much material available to compose humorous tales about frivolous, lusting, uncontrolled monks, abbots, even bishops, obviously because sexuality was discussed everywhere, and as much as priests tried to impose a certain level of morality and chastity, their own physical needs could not be fully suppressed, as we can observe in the intriguing world of misericords.

There is a hidden world in medieval carved wood art, especially found in Gothic cathedrals, that is, in the choir stalls of the cathedral canons. These are the misericords, much studied by art historians, but until today rather little understood and defy our efforts to come to terms with sexuality as hidden in medieval church art. ${ }^{74} \mathrm{~A}$ simple definition of misericords would be, for example: it "is a small wooden structure formed on the underside of a folding seat in a church which, when the seat is folded up, is intended to act as a shelf to support a person in a partially standing position during long periods of prayer. ${ }^{, 75}$ Even though today mostly cordoned off from public views, the misericords played an important role for the canons during mass. As William James Shadwell summarizes,

The Choir with its stalls was the most important and sacred part of the medieval church, and the most particular and detailed work was put into it. The stalls consist of a lifting seat (the misericord), a book rest (prie dieu), a partition between each stall (parclose), an elbow rest on the partition, often finishing in a carved subject which gave extra support to standing, a back panel and a canopy (baldaquin) usually very elaborately carved. The two latter and the

and Renaissance thinkers recognized in the bath a profound symbol of a universal rejuvenation, as most famously expressed by Cola di Rienzo who took his public bath in Rome on August 1, 1347, resorting to the mysterious tub out of porphyry used by Emperor Constantine when he was baptized as a Christian. See Reiner Dieckhoff, "antique - moderni: Zeitbewußtsein und Naturerfahrung im 14. Jahrhundert,“ Die Parler und der schöne Stil 1350-1400: Europäische Kunst unter den Luxemburgern, ed. Anton Legner. Ein Handbuch zur Ausstellung des Schnütgen-Museums in der Kunsthalle Köln, 3 (Cologne: Schnütgen-Museum, 1978), 67-93; here 85-88; Marilena Amerise, Il battesimo di Costantino il Grande: storia di una scomoda eredità. Hermes: Zeitschrift für klassische Philologie, 95 (Stuttgart: Steiner, 2005). See also Albrecht Classen, "The 'Dirty Middle Ages': Bathing and Cleanliness in the Middle Ages. With Emphasis on Medieval German Courtly Romances, Early Modern Novels, and Art History: Another Myth Buster," Bodily and Spiritual Hygiene in Medieval and Early Modern Literature: Exploration of Textual Presentations of Filth and Water, ed. A. Classen. Fundamentals of Medieval and Early Modern Culture, 19 (Berlin and Boston: Walter de Gruyter, 2017), 458-500.

71. Christoph Graf zu Waldburg Wolfegg, Venus and Mars: The World of the Medieval Housebook, trans. from the German and ed. by Almuth Seebohm (Munich and New York: Prestel, 1998); for a digitized image of this particular scene, see http://de.wikipedia.org/wiki/Hausbuch_\%28Schloss_Wolfegg\%29\#/media/File: Hausbuch_ Wolfegg_18v_19r_Badehaus.jpg.; cf. also the excellent introductory study online at: http://de.wikipedia .org/wiki/Hausbuch_\%28 Schloss_Wolfegg\%29 (both last accessed on April 15, 2015).

72. See the articles in part four of The Nature and Function of Water, Baths, Bathing, and Hygiene from Antiquity Through the Renaissance, ed. Cynthia Kosso and Anne Scott. Technology and Change in History (Leiden and Boston: Brill, 2009). Cf. also Jill Caskey, "Steam and Sanitas in the Domestic Realm: Baths and Bathing in Southern Italy in the Middle Ages," Journal of the Society of Architectural Historians 58 (1999): 170-195; Pius Kaufmann, Gesellschaft im Bad: die Entwicklung der Badefahrten und der "Naturbäder" im Gebiet der Schweiz und im angrenzenden südwestdeutschen Raum (1300 - 1610) (Zürich: Chronos, 2014); Robert Büchner, Im städtischen Bad (see note 67).

73. For an excellent selection of images, see https:/www.pinterest.com/claralovell1/medieval-sexualpleasures/?lp=true; for a rather crude discussion with very little scholarly background, typically pursuing popular opinions about the past, especially its treatment of sexuality, see https://www.oddee.com/item_ 96646.aspx. (both last accessed on Dec. 15, 2017).

74. Images of misericords can now be found on the most impressive website: http://www.misericords.co.uk/. (last accessed on Dec. 17, 2017).

75. https://en.wikipedia.org/wiki/Misericord (last accessed on Dec. 17, 2017).

International Journal of History and Cultural Studies (IJHCS) 
partition, which had replaced earlier curtains, helped to keep out the cold draughts from the aisle and a glassless triforium. ${ }^{76}$

In England alone there are ca. 3600 examples left, about half of them displaying figurale carvings, while the others are ornamental only. A surprisingly small number of these misericords contain religious themes, whereas the vast majority depict situations in everyday life, marriage, professional settings, but then also highly erotic scenes. Art historians have argued long and hard about the proper interpretation of those carvings, especially because they are often determined by a complicated hybridity, conveying both religious messages about the temporality of life and the dangers of the Seven Deadly Sins, and providing entertainment and warnings about the strong and dangerous woman. We can be certain that no misericord was simply created out of a fluke and served as a decoration only. Carvings in wood are very expensive art works, and since the misericords were mostly located in the canons' choir, they were certainly subject to critical examination by the bishop, for instance.

Betsy Chunko-Dominguez is warning us now about pursuing a straightforward reading of those wooden sculptures, either as religious with some accidental erotic features, or as lewd images with accidental religious content. "In either case, attempting to come to a concise, unified iconographic reading renders the images largely incoherent and contradictory." ${ }^{, 77}$ In fact, the number of obscene and pornographic scenes in the misericords is stunning, even for a modern viewer. Genitalia, often in grotesque sizes, are publicly presented, women perform fellatio on them, ${ }^{78}$ cats attacking genitalia, individuals exposing their behinds, etc. For Chunko-Dominguez, the meaning behind such carvings rests in the message that we as human beings are physical in our make-up, hence subject to constant decay and dying, being physical bodies that leek, spill, seep, etc. The misericord carvings would thus be constant reminders of the temporality of all human life, subject to the incessant cycle of birth and death. ${ }^{79}$ In essence, then, what the canons observed when they folded up the misericords and viewed the carvings, was a fundamental symbolism of all earthly existence: "They symbolized the Fall in the Garden, sin and sinful potential. Yet, while imperfect containers ... they were containers nonetheless, the haven of the soul and its aspirations to spiritual perfection." $" 80$

The late medieval dialogue poem Der Ackermann (ca. 1400) by the German-Czech writer Johannes von Tepl powerfully illustrates the very same dichotomy between, on the one hand, the utter contempt and rejection of the body as a vessel containing nothing but dirt, as formulated by the allegorical figure of Death (ch. 24), and as God's greatest creation, as demonstrated by the various organs and sensory parts, as the Plowman emphasizes (ch. 25) ${ }^{81}$ Can we accept such a binary opposition for the misericords as well? Countless other texts and images from the fifteenth and sixteenth centuries would easily confirm this observation of the dialectics which the treatment of sexuality has regularly evoked.

76. William James Shadwell, A Handbook of Medieval Misericords: A Hidden Gallery of Medieval Art (http://content.yellowgrey.com/ms/a_handbook_of_medieval_misericords.php). This study seems to be available only online (no date provided; last accessed on Dec. 17, 2017).

77. Betsy Chunko-Dominguez, English Gothic Misericord Carvings: History from the Bottom Up. Art and Material Culture in Medieval and Renaissance Europe, 9 (Leiden and Boston: Brill, 2017), 30.

78. Christa Grössinger, The World Upside-Down: English Misericords (London: Harvey Miller, 1997), 112; Malcolm Jones, The Secret Middle Ages: Discovering the Real Medieval World (Westport, CT, and London: Praeger, 2003), 26; Paul Hardwik, English Medieval Misericords: The Margins of Meaning (Woodbridge, Suffolk: Boydell \& Brewer, 2011), 107-08.

79. Chunko-Dominguez, English Gothic Misericord Carvings (see note 77), 65-71.

80. Chunko-Dominguez, English Gothic Misericord Carvings (see note 77), 71.

81. Johannes de Tepla, Epistola cum Libello ackermann und Das büchlein ackermann: nach der Freiburger Hs. 163 und nach der Stuttgarter Hs. HB X 23, ed. and trans. Karl Bertau (Berlin and New York: Walter de Gruyter, 1994); cf. Albrecht Classen, "Der Ackermann aus Böhmen - ein literarisches Zeugnis aus einer Schwellenzeit: Mittelalterliches Streitgespräch oder Dokument des neuzeitlichen Bewußtseins?,” Zeitschrift für deutsche Philologie 110.3 (1991): 348-73; Christian Kiening, Schwierige Modernität: der "Ackermann" des Johannes von Tepl und die Ambiguität historischen Wandels. Münchener Texte und Untersuchungen zur deutschen Literatur des Mittelalters, 113 (Tübingen: Max Niemeyer, 1998); Albrecht Classen, "Death Rituals and Manhood in the Middle High German Poems The Lament, Johannes von Tepl's The Plowman, and Heinrich Wittenwiler's Ring," Grief and Gender: 700-1700. Ed. by Jennifer C. Vaught (New York: Palgrave, 2003), 33-47. 
Considering the large corpus of available misericords both in England and on the Continent, we could certainly agree with such a reading in many cases, but we can also not ignore the fact that many of the carvings apparently delight in presenting all and every part of the human body and to convey a sense of fun resulting from this transgressive art. For instance, a misericord in the priory church at Swine in Holderness, Yorkshire, which used to be a Cistercian nunnery, displays "an exhibitionist exposing his buttocks and genitals. Moreover, his beard bears a curious resemblance to female genitalia." should, however, not ignore that the man is actually smiling at us, and his apparently elegant headgear and carefully coiffured mustache certainly makes it impossible that he would have represented a fool. Were the nuns supposed to consider the joys of all human sexuality? Were they invited to reflect upon the possible hybridity of human sexual identity?

We can be certain that the artists did not leave anything about the human body a secret and directly presented genitals and what one can do with them for personal enjoyment. At the same time, the drastic humor, combined with strong religious teachings, also finds clear expression. Even though the misericords were mostly not visible by the laity, they served the canons and other clerics as a source of entertainment, instruction, reflection, and meditation. Altogether, sexuality was very much on their mind, especially when they entered the canons' choir, for instance, and were alerted by the misericords to remember their very own human nature and to practice humbleness. After all, sexuality is a natural function of the human body, and it takes great self-discipline, energy, and dedication to repress it. Those who commissioned or authorized the misericords were fully aware of this phenomenon and obviously accepted that the canons were allowed to be reminded of sexuality, though then they were supposed to laugh about the wooden images and distance themselves from the scenes depicted, which certainly served as a warning of their own weakness and susceptibility to temptation.

Considering how much the theme of sexuality had entered even the inner sanctum of the medieval church, we will not face major challenges in interpreting the meaning of numerous late-medieval mock pilgrimage images made out of metal found in Holland and elsewhere, in which a vulva carries a penis on its top, holding a pilgrimage staff in its right hand and a rosary in its left. ${ }^{83} \mathrm{~A}$ surprisingly large number of metallic phallus figures from the late Middle Ages, either in combination with animal features, with people, or by themselves, but combined with wings, or with travel objects, such as ships, or serving in place of horses to transport a person, then also vulvae, either alone, or attached, combined, or imposed on other objects, or animals, indicate how much the discourse of sexuality permeated all kinds of social levels and classes and was not far away from the world of religion. Modern collectors and museum directors mostly kept these objects secret, but we can no longer deny their existence, though we are far away from fully grasping their significance and purpose. ${ }^{84}$

They were probably apotropaic in their primary function, but they certainly turned into hilarious objects not only intended to fend off the "Evil Eye," but also to transgress simple taboos, to present the human body in a topsy-turvy condition, focusing only on the anthropomorphized genitals, and to satirize, surprisingly, political and religious opponents, or simply the pilgrims themselves, though it seems rather far-fetched, following Malcolm Jones's argument, to assume that the pilgrims were willing to poke fun at themselves wearing these badges. ${ }^{85}$ Johan H. Winkelman now suggests that this open display of female genitals in mostly bizarre oversize served as protective instruments against the

82. Chunko-Dominguez, English Gothic Misericord Carvings (see note 77), 66.

83. Virginia Nixon, Mary's Mother: Saint Anne in Late Medieval Europe (University Park, PA: The Pennsylvania State University Press, 2004), 156 and 158; see also Jeffrey F. Hamburger, "The Visual and the Visionary: The Image in Late Medieval Monastic Devotions," Viator 20 (1989): 161-82, fig. 23.

84. Heilig en Profaan: 1000 Laatmiddeleeuwse Insignes uit de collectie H. J. E. van Beuningen, ed. H. J. E. van Beuningen and A. M. Koldeweij. Rotterdam Papers VIII. A Contribution to Medieval Archeology (Cothen: Stichting Middeleeuwse Religieuze en Profane Insignes, 1993), 258-64; see also the catalogue to the exhibition, Stadtluft, Hirsebrei und Bettelmönch: die Stadt um 1300, ed. Marianne Flüeler-Grauwiler and Niklaus Flüeler (Zürich and Stuttgart: K. Theiss, 1992), especially 434-35.

85. Malcolm Jones, The Secret Middle Ages (see note 78), 248-273; see also his "Sex and Sexuality in Late Medieval and Early Modern Art," Privatisierung der Triebe?: Sexualität in der Frühen Neuzeit, ed. Daniela Erlach, Markus Reisenleitner, and Karl Vocelka. Frühneuzeit-Studien, 1 (Frankfurt a. M., Berlin, et al.: Peter Lang, 1994), 187-304; here 195. 
seductive force of female sexuality or, in cases of grotesque phalli, as visual objects to exhibit exorbitant sexual virility. ${ }^{86}$

Such interpretations seem to be valid, and yet they do not fully capture the essential features and functions of those badges because they evoked, undoubtedly especially because of their transgressive nature, roaring laughter and alleviated the mundane monotony of the life on a pilgrimage, or they were employed during carnival and at other festive events when the Christian rules were undermined deliberately to release the stress of everyday life. ${ }^{87}$ Their crudeness is obvious, but their carnivalesque quality strikes us as most dominant since some of them display the male or the female genitals, or a combination of both, in full view. For medieval pilgrims it must have been liberating, or simply entertaining to bring home some of those grotesque but decorative ornaments out of lead, tin, bronze, or gold, although it seems questionable whether they openly presented those pornographic objects as well during mass or other serious church events.

Those badges were sold in large numbers to the enormous masses of pilgrims, at times and at special locations counting more than 100,000 people a day. ${ }^{88} \mathrm{We}$ are, in short, directly on the trail of an aspect in medieval art that has not yet been sufficiently studied and yet deserves our full attention because the topic of sexuality mattered significantly for adults at every level of society and in every social group or class. It would be a great disservice to the study of medieval art if we neglected to pay attention also to the theme of sex since it appears much more often than we might have assumed. ${ }^{89}$

Considering the extent to which we have already recognized and acknowledged the full extent of the treatment of the erotic and sexuality in medieval literature, which was also produced and consumed by members of the clergy, it does not come as a real surprise that medieval art was also deeply influenced by those themes, either dealing with them in a moralizing or a comic fashion, drawing on the basic understanding of the sexual nature of every human being, as formulated already in Genesis, or resorting to them out of prurient interests. After all, the Carmina Burana, for instance, were copied down in a monastery, probably Neustift near Brixen, Southern Tyrol, and countless other medieval manuscripts also originated from monastic scriptoria. The miniaturists did not hold back, as we can now conclude in depicting also the naked human body in all of its erotic qualities. Already the tenthcentury nun and playwright, Hrotsvit of Gandersheim, freely engaged with highly erotic materials when she composed her plays to be performed in her convent, and her religious narratives. Those all depict martyrs who are suffering as a result of sexual pursuits by heathen authority figures, but they overcome the temptation and are strong enough to resist, defying their enemies and proving their chastity and piety. ${ }^{90}$

We would have to read the medieval misericords in a similar light, as illustrative examples of the dangers of human sexuality, but we also recognize both here and there the considerable effort which the artists made to create their art works. Those who produced the highly transgressive pilgrimage badges and the illustrators of manuscripts with sexual themes obviously pursued a variety of motives, but there was no hesitation to allow sexuality to enter the picture, literally. A careful reading of medieval culture, literature, art, law, and even philosophy easily exhibits a strong tendency, if not necessity, to come to terms with this fundamental urge in human life. After all, as both the Old and

86. Johann H. Winkelman, "Mittelniederländische Tragezeichen und die nordwesteuropäische Kulturlandschaft. Zum kulturellen Transfer im Spätmittelalter," Amsterdamer Beiträge zur älteren Germanistik 63 (2007): 199219; here 203-07.

87. Ann Marie Rasmussen, "Materiality and Meaning: What a Medieval Badge Can Tell Us about Translation," Un/Translatables. New Maps for German Literatures, ed. Catriona McLoed and Bethany Wiggin (Chicago: Northwestern University Press, 2016), 215-28; she refers to the relevant research on badges, but she does not engage with the pornographic badges. For a selection of photos online, see https://www.pinterest.com/scagerbil /pilgrimage-badges/?lp=true. Very useful also prove to be www.pilgerzeichen.de; www.medievalbadges.org (all three last accessed on Dec. 19, 2017).

88. Brian Spencer, Pilgrim Souvenirs and Secular Badges. Medieval Fonds from Excavations in London, 7 (1998; London: Boydell Press in association with Museum of London, 2010).

89. Caviness, “A Son's Gaze on Noah,” The Meanings of Nudity in Medieval Art (see note 13), 125-30.

90. Albrecht Classen, "Sex on the Stage in an Early Medieval Convent: Hrotsvita of Gandersheim. A TenthCentury Convent Playwright's Successful Struggle Against the Roman Terence," Orbis Litterarum 65.3 (2010): 167-200. 
the New Testament had already confirmed, love (Song of Songs) and marriage (Wedding of Cana) were fundamental, and both were, implicitly and yet constantly, predicated on sexuality as well. The body was regarded as the worst enemy of the human soul and spirituality, and yet it was also regarded and accepted as the conditio sine qua non for all human existence, as formulated, for instance, by the seventh-century abbot John Climacus (or John the Ladder). ${ }^{91}$

It does not come as a surprise that worldly art in the Middle Ages teems much more with sexual motifs than religious art, such as the brilliant drawings in the Hausbuch Wolfegg from ca. 1480, presenting bathroom scenes, copulating couples, and other topics. ${ }^{92}$ If we scanned through the vast body of late medieval Books of Hours or paintings depicting Judgment Day, such as the one by Hans Memling (1430-1494), ${ }^{93}$ we would also detect numerous clearly sexually charged scenes, which certainly conveyed a moral and religious message, but also drew from a basic interest in sexuality and the nude body. Not surprisingly, both the numerous misericords and the corbels illustrate how much sexuality was also on the minds of the clerics, many of whom were confronted with it on a daily basis as the confessors of their parishioners.

After all, without sex there was no fertility, which thus explains why sexual images at times also entered the interior of churches. The Abbey Church of Sainte-Radegonde in Poitiers displays, in the console in the nave, a thirteenth-century male nude prominently displaying the man's penis. But there is also a female nude whose breasts are protruding, while she is spreading her vaginal lips for the viewer clearly to see, and it would make good sense that the parishioners were encouraged to look at both sculptures to remember how important sex was also for the ordinary Christian person, if performed within marriage. ${ }^{94}$ Caviness surmises that they might have served as "talismans for fertility and birthing" and did not necessarily convey any (or only) prurient interests in pornography. ${ }^{95}$ Altogether, the evidence presented here does not naively suggest that sexuality was perceived by medieval artists, theologians, writers, and philosophers the same way as by modern viewers or thinkers. Of course, the differences are remarkable especially because in the Middle Ages the naked body carried a much deeper, often a spiritual meaning. Nevertheless, we would be victims of modern myth-making if we perpetuated the popular idea that in the pre-modern world sexuality was mostly taboo and hidden behind closed doors of married couples. The topic of sex was considerably present in medieval art and served many different functions. A corbel at the church of San Pedro in Cervatos (Cantabria), ca. twelfth century, and a misericord in the choir of the cathedral of Astorga (northwestern Spain), ca. thirteenth century, or later, clearly display a couple in a 69 position. ${ }^{96}$ Was this supposed to be a warning or a reminder of our human nature, were the viewers alerted to human sinfulness or encouraged to enjoy each other's sexual body in an equal fashion? We might never find out in desired clarity, especially because the semiotics of those art works defy, until today, straightforward answers and obviously play on the profound ambivalence of sexuality in human life. We are damned if we enjoy it individually, and we are damned if we reject it collectively.

To conclude, medieval art, both secular and ecclesiastical, indicates the fundamental dilemma with our sexual nature, and our observations now also underscore that sex was a central theme after all

91. Margaret D. Kamitsuka, "Introduction," The Embrace of Eros (see note 18), 6.

92. Christoph Graf zu Waldburg Wolfegg, Venus and Mars. The World of the Medieval Housebook, trans. from the German and ed. by Almuth Seebohm (1997; Munich and New York: Prestel, 1998); for a good digital images, see online at: https://de.wikipedia.org/wiki/Meister_des_Hausbuches\#/media/File:Hausbuch_Wolfeg g_18v_19r_Badehaus.jpg.

93. For a digital collection of all of his oil paintings, see now online at: https://www.1st-art-gallery.com/HansMemling/Hans-Memling-oil-paintings.html

94. The image of the female can be found at: https://www.flickr.com/photos/martin-m-miles/24648920566; the image of the male is at: https://www.pinterest.co.uk/pin/294845106838273203/ (both last accessed on Dec. 22, 2017).

95. Caviness, “A Son's Gaze on Noah," The Meanings of Nudity in Medieval Art (see note 13), 126-29; see also eadem, "Obscenity and Alterity: Images that Shock and Offend Us/Them, Now/Then?," Obscenity: Social Control and Artistic Creation in the European Middle Ages, ed. Jan Ziolkowski (Leiden and Boston: Brill, 1998), 155-75; here 162; eadem, "Retomando la Iconografía Vaginal (Revisiting Vaginal Iconography," Quintana 6 (2007): 13-37.

96. Bartz, Karnein, and Lange, Liebesfreuden im Mittelalter (see note 5), 101. They perceive here sculptural warnings against the sexual depravity of the Islamic world, which might be possible; and yet the aesthetic quality of those art objects speaks a different language. 
within the medieval discourse on the conditions of human existence. Many artists engaged with this topic, working in wood (misericords), metal (pilgrimage badges), creating manuscript illuminations, woodcuts, or lithographs and etchings. For the Church, often serving as the main patron of medieval artists, the public treatment of sexuality made possible to discuss human frailty, bodily needs, the power of physical temptations, lack of self-control, the danger of the devil, and of women, of course, for men's salvation. At the same time, despite the common hortative messages, there was also a clear sense of playfulness and experimentation, an urge to transgress social norms and ethical and moral ideals. In general, we would have to say, sexuality was omnipresent and ubiquitous in the Middle Ages, at least much more than scholars have traditionally acknowledged. This means for us that we have to incorporate this theme in many other research areas, involving social-economic, political, religious, literary, and ethical and philosophical aspects.

Citation: Albrecht Classen, "Sexuality in Medieval and Early Modern Art: From the Corbels and Misericords to Late Medieval Manuscript Illustrations". International Journal of History and Cultural Studies (IJHCS). vol 4, no. 4, 2018, pp. 1-19. doi: DOI: http://dx.doi.org/ 10.20431/2454-7654.0404001.

Copyright: (C) 2018 Authors. This is an open-access article distributed under the terms of the Creative Commons Attribution License, which permits unrestricted use, distribution, and reproduction in any medium, provided the original author and source are credited. 